\title{
ЛЕКСИКО-СЕМАНТИЧЕСКИЕ СПОСОБЫ ВЫРАЖЕНИЯ РЕЧЕВОЙ АГРЕССИИ В АНГЛИЙСКОМ И РУССКОМ ЯЗЫКАХ
}

\author{
А. В. Денисова \\ Южсный федеральный университет, Институт филологии и межкультурной коммуникации
}

\section{LEXICO-SEMATIC WAYS OF EXPRESSING VERBAL AGGRESSION IN THE ENGLISH AND RUSSIAN LANGUAGES}

\author{
A. V. Denisova \\ Rostov-on-Don, Southern Federal University, Institute of Philology and Intercultural Communication
}

\begin{abstract}
Аннотация: статья посвящена изучению основных лексико-семантических и стилистических способов выражения речевой агрессии как проявления эмочионального реагирования в процессе межличностной коммуникации, а также источников ее формирования в английском и русском языках. Актуальность темы определена нарастанием агрессии в современном обществе, возникновением конфликтов различного характера и уровней, частота проявления которых также обусловливается нарастающей интенсивностью контактов между представителями различных этнокультурных групп. Межличностные конфликты находят выражение, как правило, в речевой и неречевой агрессии. Вербальная агрессия маркируется бранными, оскорбительными словами в адрес раздражителя. Подобные неконструктивные способы взаимодействия лишают коммуникантов возможности достижения взаимопонимания, установления контактов, несут в себе риск разрушения сочиальных связей, негативных последствий для жизнедеятельности людей, групп и общества в иелом. Вербальная агрессия не имеет временных или четко очерченных этнических характеристик, не ограничена она и рамками определенного сочиокультурного контекста. Интерпретативная модель коммуникаџии как агрессивной, ущемляющей чувство достоинства, причиняющей моральные страдания может сформироваться у адресата и при отсутствии у адресанта намерения совершить осознанный агрессивный вербальный акт. Причина такого восприятия адресатом обращенной к нему речи в особенностях регионального типа коммуникации, к которому принадлежит адресант, различия в социальном статусе коммуникаторов, их этно- и культурно-специфичной принадлежности. Мошным фактором в распространении речевой агрессии являются средства массовой информачии. Интерпретируя события с точки зрения собственного мнения, своих предпочтений, СМИ манипулируют сознанием читателей с помощью разнообразного арсенала речевых средств, влияют на поведение коммуникантов, их оценку событий, формируют поведенческие, речевые паттерны, в том числе и агрессивные.
\end{abstract}

Ключевые слова: речевая агрессия, вежливость, грубость, преднамеренная речевая агрессия, непреднамеренная речевая агрессия, коммуникативное поведение, этнический стереотип.

Abstract: the article studies the main lexico-sematic and stylistic ways of expressing verbal aggression as an emotional reaction occurring in the act of interpersonal communication as well as the sources of its formation in the English and Russian languages. The significance of the topic is explained by the rising level of aggression in the modern society, various types and levels of conflicts that take place, the frequency of which is related to the intensifying contacts between the representatives of different ethno-cultural groups. Interpersonal conflicts are, as a rule, expressed in verbal and non-verbal aggression. Verbal aggression is marked by offensive words and abusing language addressed towards the source of annoyance. Such destructive ways of communication deprive the members of a communicative act of an opportunity to reach common ground, establish rapport, in addition they are highly likely to damage social connections and are toxic for life-sustaining activity of individuals, groups and the whole society. Verbal aggression does not have particular time or ethnic frames, neither is it limited by

(C) Денисова А. В., 2021

Контент доступен под лицензией Creative Commons Attribution 4.0 License.

The content is available under Creative Commons Attribution 4.0 License. 
certain socio-cultural context. Being descried as aggressive, interpretative model of communication may be considered by the addressee as the one infringing the sense of self-worth, causing emotional distress, even though the addresser did not intend to commit an act of verbal aggression. The cause of such a perception lies in the regional communicative features the addressee belongs to, differences in social statues of the members of communication, their specific ethic and cultural belonging. The media is a powerful means of spreading verbal aggression. Interpreting the events from its own perspective, being guided by its own preferences, the media manipulates the readers' opinions being armed with a variety of verbal techniques, influence the behaviour of the members of the communicative act, the way they evaluate the events, shape behaviour and verbal patterns, including the aggressive ones.

Key words: verbal aggression, politeness, rudeness, intentional verbal aggression, unintentional verbal aggression, communicative behaviour, ethnic stereotype.

\section{Введение}

В современном языкознании обозначилась тенденция в исследовании проблем, посвященных изучению человеческого фактора в языке и речи, - лингвистическое оформление выражаемых эмоций, чувств, в том числе агрессивных. Вектор научных поисков обусловлен нарастанием агрессии в современном обществе. Причиной таких проявлений стали процессы глобализации, активное экономическое развитие многих стран, усиление контактов представителей различных этнокультурных групп, трансформация ценностно-смысловых ориентиров, пропаганда средствами массовой информации, интернет-ресурсами жестокости и насилия через демонстрацию жестокого поведения как способа решения проблем. Деструктивные последствия такого влияния наиболее болезненны для сферы межличностного общения, которое сопряжено со столкновением мнений, различных точек зрения, интересов.

Дополнительным конфликтогеном становится взаимодействие этнофоров в деловой и неформальной сферах. Это связано с тем, что большая часть правил общения основывается на общечеловеческих, но часть реакций обусловлена этнической спецификой выражения эмоций, поведенческих норм, вербального коммуникативного поведения, непринятие которых иноэтносом нередко порождает конфликт, находящий, как правило, выражение в агрессии - вербальной и невербальной.

Вербальная агрессия маркируется бранными, оскорбительными словами в адрес раздражителя. Такая эмоциональная разрядка - открытое выражение эмоций и чувств, - безусловно, позволяет участникам конфликта «сбросить» нервное напряжение, самоутвердиться за счет унижения, оскорбления противоположной стороны. Подобные проявления становятся деструктивными факторами не только для процесса общения, но и несут в себе риск разрушения социальных связей, негативных последствий для жизнедеятельности людей, групп и общества в целом.

Проблема. В настоящее время Европа все более активно осваивается нашими соотечественниками, и неконструктивные способы взаимодействия лишают коммуникантов возможности достижения взаимопонимания, установления контактов, а также могут стать причиной конфликтов при столкновении субъектов культуры - носителей различных культурных ценностей и норм.

Цель исследования состоит в изучении основных лексико-семантических и стилистических способов выражения речевой агрессии как проявления эмоционального реагирования в процессе межличностной коммуникации в английском и русском языках, а также источников ее формирования.

\section{Методы исследования}

В основу методологического исследования положены труды отечественных и зарубежных психологов K. Изарда, A. Buss, G. Carey, D. R. Miles, Р. Бэрона, лингвистов Ю. Д. Апресяна, В. И. Жельвис, А. Н. Леонтьева, Ю. В. Щербининой, О. В. Масловой, социологов Н. Garfinkel и др. Изучение феномена коммуникативной агрессии в рамках данной статьи осуществлялось на материалах интернет-опросов, печатных СМИ как наиболее чувствительных индикаторов изменений в языковой ситуации.

В работе использованы методы: структурно-семантический, концептуальный, сопоставительноописательный.

\section{Результаты исследования}

Дефиниции термина «агрессия»/aggression в различных словарях позволили выделить наиболее значимые, а также формальные свойства данного понятия.

В «Толковом словаре современного русского языка» С. И. Ожегова и Н. Ю. Шведовой понятие агрессии в прямом ее значении определяется как нарушение одним государством суверенитета, территориальной неприкосновенности, политической независимости другого государства с применением вооруженной силы. В переносном значении - вызывающая враждебность открытая неприязнь [1].

В толковом словаре Д. Н. Ушакова трактовка слова «агрессия» также объясняется наступлением, нападением, агрессивным отношением к чему-либо. 
Большой психологический словарь под редакцией Б. Г. Мещерякова и В. П. Зинченко [2] дает комплексную характеристику исследуемого понятия. Агрессия в трактовке словаря предстает феноменом, мотивирующим деструктивное поведение, что противоречит нормам (правилам) сосуществования людей в обществе, наносит вред объектам нападения (одушевленным и неодушевленным), приносит либо физический ущерб людям, либо вызывает у них психологический дискомфорт».

Аналогичную трактовку находим в одной из словарных статей Большого толкового социологического словаря, где агрессия определяется как «действие, поведение, имеющее целью нанесение ущерба (морального, физического и т. д., вплоть до полного уничтожения) другому существу или объекту» [3].

Оксфордский английский словарь для изучающих язык на продвинутом уровне дополняет определение анализируемого дефиниендума эмоциональными характеристиками - чувством гнева и ненависти, выражающимися в угрозе и насилии [4].

Dictionary.com Unabridged: «The action of a state in violating by force the rights of another state, particularly its territorial rights; aggression upon one's rights» / «насильственное нападение или угрозы одним лицом на другое лицо, нарушение его прав, или нападение или угрозы одной страной против другой страны, неспровоцированная военная агрессия» [5].

Oxford English Dictionary (OED): «Feelings of anger and hate that may result in threatening or violent behavior / «чувства гнева и ненависти, которые могут привести к угрожающему или насильственному поведению» [6].

Таким образом, обобщенное значение слова «агрессия», составленное на основе приведенных трактовок в современных словарях, можно определить как действие или поведение, которое агрессивно нарушает чьи-либо права, нападки и атакующие действия.

Содержательная сторона понятия «агрессия» раскрывается в многоаспектных интерпретациях исследователей в различных областях науки - лингвистики, социологии, этнопсихологии, анализ которых позволяет определить рассматриваемое понятие как деструктивный элемент коммуникации, разрушающий модель взаимодействия участников общения [7].

Для нашего исследования наибольший интерес представляют исследования в области вербальной агрессии. Так, Ю. В. Соколова среди маркеров речевой агрессии называет тон, громкость речи [8].

И. А. Стернин отмечает, что допущенная в процессе общения грубая ошибка незамедлительно переводит общение в разряд неэффективного, что означает «коммуникативное самоубийство» [9].
Речевая агрессия, по мнению Ю. В. Щербининой, - это словесное воплощение негативных эмоций, чувств, намерений в оскорбительной, грубой, неприемлемой в данной ситуации речевой ситуации форме с применением оскорблений, угроз, насмешек - всего того, что «затрудняет полноценный обмен информацией, тормозит ее восприятие и понимание собеседниками друг друга. Она - спутник любой ссоры».

Оцениваясь менее деструктивно, чем физическая, речевая агрессия становится основой агрессии физической, формируя модель социально неприемлемого поведения [10; 11].

Психологи Р. Бэрон, Д. Ричардсон понимают вербальную агрессию как «...форму поведения, нацеленную на оскорбление или причинение вреда другому живому существу» [12]. А. Басс более категоричен в определении вербальной агрессии, называя ее основными признаками ссору, крик, визг, а содержанием словесных ответов - угрозу, проклятие, ругань [13]. К. Изард в характеристику речевой агрессии вводит мотивационный компонент, определяя ее как «враждебное действие или поведение», которое обусловлено внешним мотивом или ситуацией [14]. Арнольд Басс и Вильям Перри классифицировали речевую агрессию как одну из враждебных реакций, считая ее альтернативой физической [15].

Содержание понятия «агрессия» включает категории вежливость, невежливость, грубость, которые являются инструментами коммуникативного баланса

Невежливость и грубость - категории, образующие систему коммуникативных стратегий, прагматических категорий, относящихся к специфической системе коммуникативных стратегий и тактик и имеющих целью умышленного или неумышленного нанесения эмоционального урона лицу собеседника и снижение эффективности бесконфликтного коммуникативного взаимодействия.

Вежливость/невежливость - понятия, называющие такие поведенческие проявления, которые либо соответствуют общепринятым в обществе стандартам, либо не соответствуют им.

Грубость - более сложное, многокомпонентное понятие. Оно не только дает оценку ситуации, но и выражает отношение к говорящему [16]. Причем эти «эффекты» могут быть как сознательно сформированы адресантом, так и быть таковыми исключительно в восприятии коммуниканта. Следовательно, речевая агрессия как дискурсивный феномен может быть преднамеренной и непреднамеренной.

Преднамеренная речевая агрессия - вербальное проявление негативной реакции, имеющей целью социальную дискредитацию объекта и выраженной в вызывающей, оскорбительной словесной форме, уничижительной насмешке, угрозе, обвинении, грубом отказе, а также и в более мягких формах - иронии, 
намеке. Но как правило, подобные формы от наиболее мягких до жестких направлены на то, чтобы унизить, уколоть, создать отрицательный образ партнера. Сознательно организованная участниками агрессивная интеракция формирует инвективную коммуникативную реальность при помощи табуированных лексических единиц, дисфемизмов, причем, как правило, неотъемлемой частью коммуникативного пространства, позволяющей безошибочно интерпретировать поведение говорящего, является фреймовый сценарий, когда говорящий не только сообщает информацию, но и обогащает ее косвенной информацией высотой голоса, его громкостью, интонированием, которые не оставляют адресату сомнений относительно чувств и намерений говорящего [17].

Для усиления экспрессии спонтанной речевой реакции отрицательные, вызывающие агрессию качества не указываются, а замещаются аналогами, как правило, с использованием ресурсов стилистически сниженной лексики, различающихся по силе оскорбления в соответствии с характером языковой культуры, к которой принадлежит говорящий.

Непреднамеренная речевая агрессия характеризуется тем, что адресат не имел целью обидеть собеседника, который, тем не менее, воспринимает обращенную к нему речь как оскорбительную, унижающую его человеческое достоинство [18].

Подобная ситуация складывается при неоправданно повышенной громкости речи, негативной окраске тона, пренебрежительной позе собеседника, присвоении себе доминирующей позиции с проявлением ее в коммуникативной атрибутике, но не принимаемой такой позиции собеседником.

Такой вид коммуникативного общения может, например, осуществляться между руководителем и подчиненным в случае нарушения начальником норм деловой этики. К подобным нарушениям относятся проявления доминирования, выражающиеся в манерности, надменном, пренебрежительном интонировании речи, применении императивных форм воздействия на подчиненных и коллег. Проявлением агрессии в этом случае станет использование в речи цитат, фразеологических оборотов, названий, острот, понятных говорящему, но не понятных адресату. Например, «Вернемся к нашим баранам». Это выражение означает призыв вернуться к существу вопроса, началу беседы, берет начало из средневекового источника, в котором излагается содержание судебного иска суконщика к пастуху, укравшему со слов суконщика у него овец. Истец постоянно отвлекался от темы, и судья возвращал его к сути проблемы вышеназванной фразой, ставшей крылатой. Если коммуникант не знаком с данным фразеологическим оборотом, и слово «баран», употребляющееся в русской речевой традиции в негативном контексте, примет на свой счет, то реплика будет им расценена как оскорбление. Библейское выражение «Не мечите бисер перед свиньями», произнесенное перед подчиненными как укоризна за непонимание и воспринятое ими буквально, также способно привести к конфликтной ситуации. Или благое намерение похвалить человека, выраженное словами «вы хорошо выглядите для вашего возраста», вряд ли будет положительно расценено тем, к кому эти слова адресованы. Источником непреднамеренной агрессии может стать и употребление языковой единицы без учета ее эмоционального компонента: «бухгалтерия сводит последние счеты с уходящим годом».

Грубость, как и вежливость, имеет этномаркированные особенности, и уровень ее принятия различными культурами, т. е. степень толерантности, различен. Это в большей степени относится к непреднамеренной речевой агрессии, которая может быть обусловлена несовпадением ментальных особенностей этносов и этнических групп.

Существенным агрессантом в межэтническом общении, несущим конфликтогенный потенциал, является восприятие интонирования другого языка противоположным коммуникантом. Многие иностранцы характеризуют русскую речь как невероятно жесткую, а разговаривающих на русском языке принимают за людей, выясняющих между собой отношения и готовых начать драку. Другим иностранцам кажется, что русские в разговоре между собой смеются над ними, поэтому общение между собой наших соотечественников в присутствии иностранцев, не знающих русского языка, вызывает у них негативные эмоции.

В английском языке, как и в русском, и в любом другом, есть фразы, значение которых можно понять только из контекста, что при слабом владении языком чревато межличностными осложнениями. Например, фразу nice one / молодец в разговорном варианте используют в значении well done или thanks. В ситуации отлично проведенного футбольного матча можно услышать одобрительное «Nice one!», а если вы опрокинули чашку горячего кофе на соседа по столику, то рискуете также услышать в свой адрес «Nice one!», но уже с оттенком сарказма - «Молодец, кретин!»

Также в английском языке есть слова, которые несут нейтральный смысл, и есть их синонимы с разными оттенками значений. Например:

a man, a friend - нейтральное;

a guy, buddy, old chap, pal, fellow - разговорное, неформальное.

Будет некорректно, если вы скажете своему начальнику «hey, buddy».

В исследованиях по этнометодологии указывается, что у каждого народа исторически сложились 
собственные представления о вежливом или невежливом поведении [19]. Например, позитивный для западной культуры известный жест, обозначающий «ОК», обращенный к испанцу, может стать источником его агрессивного поведения. Поэтому, рассматривая феномен агрессии как социальный феномен, необходимо учитывать систему ценностей английской и русской культур, которые и сформировали специфику мышления, стратегии поведения русских и англичан [20].

Английская и русская культура - это два противоположных края Европы, два кардинально различных типа культуры. У англичан - культ личного, индивидуального, «privacy», русские - общественники, с приоритетом коллективного перед личным.

Особенности коммуникативного поведения англичан являются выражением их национального характера. Традиционный этностереотипный портрет англичан содержит следующие характеристики: снобизм, эгоцентризм, сдержанность, консерватизм, независимость и уверенность в себе.

Русские же в глазах представителей других национальностей считаются напористыми, самоуверенными, бесцеремонными и своенравными, легко переходящими от безудержного веселья к вспышкам гнева. Такие личностные особенности русского человека обусловили относительно терпимое отношение общества к использованию обсценной лексики, которая фиксируется в специализированных лексикографических изданиях.

Напротив, эмоциональная уравновешенность англичан проявляется в сдержанности при отборе лексических средств выражения, в замене прямых оценочных суждений на недосказанность, намек, в избегании резкой критики и явного неодобрения.

Особенности английского характера проявляются и в эмоционально-оценочной неоднозначности слова: английские бранные слова могут передавать как негативные, так и позитивные эмоции. Например, fuck off - отвали (или еще жестче в русском варианте), а this is fucking brilliant - потрясающе! Причем, fuck off англичанин может произнести агрессивно, имея целью нанести оскорбление, но может произнести его и с улыбкой, дружески похлопывая по плечу. Определить негативную коннотацию слова в такой коммуникативной ситуации возможно только с помощью анализа экстралингвистических и интралингвистических признаков. В русском языке такая двусмысленность исключена: лексико-стилистические характеристики всегда идентичны, степень агрессии маркируется экспрессией и лексическим уровнем бранного слова.

Опрос жителей Объединенного Королевства британским интернет-порталом показал, что английские ругательства имеют четыре степени градации:
- относительно легкие (mild). Среди них - arse, bloody, crap, damn, cow, goddam, Jesus Christ, minger. Bloody (кровавый) может выступать как литературным словом, так и ругательным в зависимости от контекста;

- средние (medium) - bitch, bullshit, feck, pissed/ pissedoff, sonofabitch;

- грубые (strong) - dick, knob, bastard, dickhead. Bastard, которое означает «незаконорожденный ребенок», в конфликтной ситуации может быть употреблено в значении «ублюдок»;

- очень грубые (very strong) - cunt и motherfucker.

Логично, что формирование словарей бранных (в английских словарях они идут с пометкой «derog», (derogatory) - оскорбительные, либо «coarse lang» оскорбительные) слов английского языка происходит в основном на материалах изучения речи молодежи.

В языке уравновешенных англичан обсценная лексика присутствует, но официальные издания такие слова не фиксируют, они являются табуированными.

Тем не менее новая версия словаря Collins English Dictionary уже включает в себя 70 нецензурных слов, что говорит об изменениях, происходящих в английском языке под влиянием как внутренних законов развития языка, так и под влиянием экстралингвистических причин [21].

Наиболее мощным каналом распространения агрессии и формирования устойчивых агрессивных речевых форм являются СМИ. Анализ лексико-семантических средств на основе материалов периодических изданий Великобритании, таких как Тhe Daily Mail, The Guardian, The Washington Post, The Times, The Independent, позволяют выделить темы, вызывающие негативные эмоциональные реакции у сдержанных англичан, - национальная система здравоохранения, низкая заработная плата отдельных категорий граждан.

Развитие темы публикации 'Anyone saying all their staff are on minimum wage in the garment industry is a fraud:' 'Sweatshop' owner of Boohoo factory confesses he pays workers a shocking $£ 4$ an hour / «Любой, кто говорит, что все их сотрудники получают минимальную заработную плату в швейной промышленности, является мошенником: владелец фабрики Вооһоо Sweatshop признается, что платит работникам шокируюшие $£ 4$ в час» продолжилось в следующих комментариях: 1. Capitalism, what do you naive idiots ехресt? / Капитализм, что вы наивные идиоты ожиdaeme? 2. I wonder if the owners of the business were lapping it up, when all all those idiots taking the knee for them / Интересно, не скупились ли владельцы бизнеса, когда все эти идиоты встали на колени за них? В таких высказываниях посредством повторяющегося агрессивного негативизма idiots выражается отношение авторов к конкретным людям - другим авторам 
комментариев, работникам, влачащим нищенское существование.

Дальнейший лексико-семантический анализ газетных статей позволил определить следующие способы выражения речевой агрессии:

- лексемы с однозначно отрицательными семантическими оценками (негативной коннотацией);

- ирония, критические замечания в адрес известных политиков, общественных деятелей, известных личностей.

A slap in the face': how racial bias dogs US coronavirus response at every level / «Пощечина»: какрасовые предубеждения влияют на реакцию США на коронавирус на каждом уровне.

Is the UK's 'golden era' of relations with China now over? / Неужели «золотая эра» отношений Великобритании с Китаем уже закончилась?

Tania Branigan examines whether a much-promoted 'golden era' between the two countries is at an end / Таня Брэниган из Guardian исследует, подходит ли к концу широко рекламируемая «золотая эра» между двумя странами.

The two-state solution is a political fiction liberal Zionists still cling to / Решение о двух государствах - это политическая фикичи, за которую до сих пор цеепляются либеральные сионистьл.

Israel's impending annexation of the West Bank has put the fate of the two-state solution - or, perhaps more accurately its death - back in the headlines. Yet neither Benjamin Netanyahu's announcement of his annexation intentions, nor the Trump "peace plan", killed the chances of two states, which ceased to be realistic long ago / Предстоящая аннексия Израилем Западного берега поставила судьбу решения о двух государствах-или, точнее, его смерти - в заголовки газет. Тем не менее ни заявление Бенджамина Нетаньяху о своих намерениях аннексии, ни «мирный план» Трампа не убили шансы двух государств, которые давно перестали быть реалистичными.

Anger at Seoul mayor Park Won-soon's funeral as accuser says he sent sexual images / Скандал на похоронах мэра Сеула Пак Вон-Суна, обвинитель утверждает, что он прислал свои сексуальные изображения своей сотруднице.

'Invisible ink' used to fix Moscow state housing contract / «Невидимые чернила» использовались для фиксачии Московского государственного жилищного контракта.

Housing officials in Moscow have been accused of embezzling money from the city budget by using invisible ink on contracts in an incident being held up by Kremlin critics as evidence of a deep-seated culture of corruption / Московские чиновники, занимающиеся жилищным строительством, обвиняются в хищуении денег из городского бюджета, используя невидимые чернила на контрактах в инцииденте, который критики Кремля считают свидетельством глубоко укоренившейся культуры коррупции.

Thousands joined demonstrations across the region in an unprecedented show of dissent / Тысячи присоединились к демонстрациям по всему региону в беспрецуедентной демонстрации инакомыслия (о поддержке жителейг. Хабаровска своего губернатора).

Up until the end even cabinet ministers were kept in the dark. Concerned that rabbits would leak rather than leap out of his hat, Rishi Sunak adopted a trick practised by his predecessor George Osborne. So when the cabinet was assembled to be briefed on the details of Mr Sunak's Covid recovery package, key elements were deliberately omitted / До кониа даже кабинет министров держался в темноте. Обеспокоенный тем, что кролики будут вытекать, а не выпрыгивать из его шляпь, Риши Сунак принял трюк, практикуемый его предшественником Джорджем Осборном.

Too Much and Never Enough by Mary L Trump review - the president's niece on a family hell / Слишком много и никогда не хватает: обзор Мэри Л. Трамп - племянница президента в семейном аду.

Imagine the worst family dinner you've ever attended, full of petty rivalries, casual bigotry, patriarchal bullying and simmering resentments over money. Recall the loudmouth uncle who hijacks every gathering, radiating entitlement and braggadocio. Throw in a heavy dose of alcoholism, contested wills and a Darwinian culture of brutal one-upmanship. Then imagine that bombastic uncle somehow becomes president of the United States and you may begin to understand where Mary L Trump is coming from in this book / Представьте себе худиий семейный ужин, который вы когда-либо посещуали, полный мелкого соперничества, случайного фанатизма, патриархальных издевательств и кипящчих обид из-за денег. Представьте крикливого дядю, который верховодит каждым собранием, излучая превосходство и хвастовство. Добавьте сюда тяжелую форму алкоголизма, спорные завещзания и Дарвиновскую культуру жестокого единоличного управления. Затем представьте себе, что напьщенный дядя каким-то образом становится президентом Соединенных Штатов, и вы поймете, откуда взялась Мэри Л. Tрамп в этой книге.

Kremlin paranoia triggers surge in espionage charges / Кремлевская паранойя вызывает всплеск обвинений в шиионаже.

Bumbling Stasi agents made up reports and put lovers on payroll / Неуклюжие агенты Штази составляли отчеты и платили любовникам зарплату.

Анализ лексем из приведенных текстов - corruption annexation, instigator, mentally-deranged, selfish, total, ultimate, unbridled, unpredictability, hell, worst, rivalry, bullying, bragging, cruelty, bigotry, bombast, 
alcoholism, dissent, espionage, the superiority - показывает, что данные лексемы не являются стилистически нейтральными, имеют негативную коннотацию и выражают субъективную оценку автора.

Пренебрежительный тон, насмешка в отношении известных лиц, государств - pompous uncle, Bumbling Stasi agents, Kremlin paranoia, rabbits from a hat, family hell - формирует у читателей соответствующее отношение к упоминаемым лицам, государствам, создает у них устойчивый репертуар речевого поведения. Ироническая форма высказывания не является этнообусловленной и носителями русского и английского языка воспринимается как агрессивная:

- если речевой акт расценивается адресантом как способ самоутверждения говорящего, лишая адресанта его коммуникативных прав;

- если агрессор одновременно с иронией демонстрирует к противоположной стороне личное отношение - scorn contempt / презрение, высокомерие.

Следовательно, как речевую агрессию можно считать сарказм, демонстрирующий имплицитные интенции автора, его превосходство над объектом своей публикации. Такая интонация отмечается в отношении Кремля, президента Америки Трампа, отчасти - Бориса Джонсона, премьер-министра Великобритании. Подобный способ подачи информации формирует и закрепляет у читателей последующими повторениями такие эмоциональные реакции, как негатив и ожесточение.

Неологизм, созданный автором в следующем фрагменте «They are building a Trump-Centric Movement. But don't call it Trumpism»/ «Они создают движение, ориентированное на Трампа. Но не называйте это трампизмом», выполняет не только экспрессивно-оценочную функцию, но и удовлетворяет потребность автора в точном определении одиозного, по его мнению, личностного политического стиля лидера и в выражении собственного отношения к данному политическому деятелю.

Публикации, освещающие внутренние события страны, - спортивные новости, бизнес, жизнь читателей, занимательные истории - созданы с помощью нейтральных, стилистически не окрашенных слов. Поэтому закономерно, что знаменитое толерантное отношение англичан к представителям других национальностей заметно трансформируется в такое состояние, которое можно назвать «обратной толерантностью», проявляющееся в раздражении и призывах к радикальным мерам по отношению к беженцам, многочисленным мигрантам, появление которых на континенте обусловлено как процессами глобализации, так и военными действиями на Ближнем Востоке, в негативном восприятии внешних событий, внутренней и внешней политики отдельных государств, в частности России.
К таким выводам приводит анализ комментариев к газетным статьям соответствующей тематики.

Публикация "Beijing is crushing human rights in Hong Kong, and is accused of genocide against the Uighurs. The world cannot stand by"/ «Пекин нарушает права человека в Гонконге и обвиняется в геноциде против уйгуров. Мир не может стоять в стороне» вызвала у читателя следующую реакцию: "To tear gas ethnic minority protesters and thump a bible for the cameras" / «Слезоточивый газ - протестуюшим этническим меньшинствам, и при этом размахивают Библией перед камерой!»

Статья об аресте нелегалов российскими полицейскими под заголовком "Spread-eagled against the wall and marched off single-file: How Russia deals with illegal immigrants" / «Распластавшись у стень и маршируя гуськом: как Россия расправляется с нелегалами» сопровождалась следующими комментариями:

- "So why do we have a problem shipping illegals back to the previous country when they have no papers?" / «Так почему у нас проблема с отправкой нелегалов в предыдущую страну, когда у них нет документов?»;

- "Why can't we do that here?!" / «Почему мы не можем сделать это здесь?!»;

- "Perhaps we should import Russian police?" / «Возможно, мы должны импортировать российскую полициию».

Причем часть комментариев были настолько экспрессивными, что их содержание нарушало нормы британского общества, и были удалены модераторами.

Приведенные высказывания несут в себе скрытую агрессию, выражающуюся в экспрессивном выражении мысли, призывах к жестким мерам ("To tear gas ethnic minority protesters"), явном одобрении действий российских полицейских.

Тема нелегалов, ставшая для англичан источником наибольшей агрессии, воплощается в специфических лексических формах: в разряде самых грубых английских слов находятся слова с расистской окраской: nigger (черномазый), paki (пакистанць), slitty eyed (узкоглазый - оскорбление людей с азиатской внешностью).

Анализ характера публикаций центральных газет России «Аргументы и факты», «Аргументы недели», «Ведомости», «Известия», «Комсомольская правда», «Новая газета», «Правда», «Российская газета», «Совершенно секретно» показал, что заголовки и содержание статей российских изданий в освещении деятельности глав государств, политиков не содержат прямой агрессии, журналисты не используют такие лингвостилистические средства, которые бы формировали у читателя имплицитные структуры и порождали скрытые подтекстовые смыслы.

Тем не менее незначительное число заголовков содержат слова, относящиеся к лексике ограничен- 
ного употребления - «воровской общак», «сел в тюрьму», причем эти идиомы употреблены в отношении высокопоставленных лиц, известных политиков. Цель - снижение статусности лица через придание комизма описываемой ситуации, что формирует высокомерное, пренебрежительное отношение к герою публикации и, к сожалению, закрепляет практику употребления подобных слов.

Отмечены негативизмы, которые, обладая экспрессивно-оценочным характером воздействия, надолго сохраняются в памяти, заменяя информированность эмоциональной памятью, например: «Ход слоном. Как король Испании Хуан Карлос погорел на любовнице»; "Охота на слонов с последующим разоблачением»; "Поперед Батьки. Кто составит конкуренцию Александру Лукашенко на выборах?»

Подмена понятий, смещение акцентов в освещении трагических событий формируют порочный эмоциональный отклик на события подобного рода: «Армения и Азербайджан обменялись обстрелами».

Рассмотренные приемы, используемые российскими СМИ, не несут признаков речевой агрессии, но снижают культурный уровень как поставщиков, так и потребителей информации, что в случае международных контактов несет риск пополнения негативных характеристик национального характера русских в сложившемся этническом стереотипе.

\section{Выводы}

Вербальная агрессия не имеет временных, четко очерченных этнических характеристик, не ограничена она и рамками определенного социокультурного контекста. Интерпретативная модель коммуникации как агрессивной, ущемляющей чувство достоинства, причиняющей моральные страдания может сформироваться у адресата и при отсутствии у адресанта намерения совершить осознанный агрессивный вербальный акт. Причина такого восприятия адресатом обращенной к нему речи - в особенностях регионального типа коммуникации, к которому принадлежит адресант, различия в социальном статусе коммуникаторов, их этно- и культурно-специфичной принадлежности. Общение может расцениваться русскими и англичанами как агрессивное, нарушающее моральные и правовые нормы в том случае, если коммуникативный акт несет в себе следующие признаки:

1) открытое проявление неприязненного отношения;

2) демонстрация намерений физического воздействия;

3) применение в речи языковых форм, в том числе и сниженной лексики, эксплицирующих враждебное состояние;
4) использование специфических форм эмоционального воздействия, ущемляющих чувство достоинства адресата.

Мощным фактором в распространении речевой агрессии являются средства массовой информации. Интерпретируя события с точки зрения собственного мнения, своих предпочтений, СМИ манипулируют сознанием читателей с помощью разнообразного арсенала речевых средств, влияют на поведение коммуникантов, их оценку событий, формируют поведенческие, речевые паттерны, в том числе и агрессивные.

\section{ЛИТЕРАТУРА}

1. Ожегов С. И., Шведова Н. Ю. Толковый словарь русского языка. Изд. 4-е, доп. М., 1997.

2. Большой психологический словарь / под ред. Б. Г. Мещерякова и В. П. Зинченко. URL: https:// psychological.slovaronline.com/41-AGRESSIYA

3. Большой толковый социологический словарь. URL: https://gufo.me/dict/social_dict

4. Oxford Advanced Learner's Dictionary. Oxford, 2000.

5. Dictionary.com Unabridged. URL: http://dictionary. reference.com/browse/aggression

6. Oxford English Dictionary. URL: https://www. oxfordlearnersdictionaries.com/definition/english/aggression? $\mathrm{q}=$ aggression

7. Якимова Н. С. Вербальная агрессия как актуальный феномен современного общества // Вестник Кемер. гос. ун-та. 2011. № 1 (45). С. 184-188.

8. Соколова О. И. В портфель специалиста-международника : осознанная и неосознанная речевая агрессия. URL: http://www.my-luni.ru/journal/clauses/75/

9. Стернин И. А. Коммуникативное поведение как предмет описания. URL: http://homepages.tversu. $\mathrm{ru} / \sim$ susov/Sternin.htm

10. Щербинина Ю. В. Речевая агрессия. Территория вражды / Ю. В. Щербинина. М. : Форум, 2012. 400 с.

11. Щербинина Ю. В. Русский язык. Речевая агрессия и пути ее преодоления : учеб. пособие. 3-е изд., стер. М. : ФЛИНТА, 2018. 224 c. URL: https://www.litmir.me/ $\mathrm{br} / \mathrm{b}=211416 \& \mathrm{p}=1$

12. Бэрон Р., Ричардсон Д. Агрессия. СПб. : Питер, $1998.336 \mathrm{c}$.

13. Collins English Dictionary. URL: https://www. collinsdictionary.com/dictionary/english/moon

14. Изард К. Е. Эмоции человека. М. : Изд-во МГУ, $1980.552 \mathrm{c}$.

15. Buss A. H. \& Perry M. The aggression questionnaire // Journal of Personality and Social psychology. 1992. № 63. Pp. 452-459.

16. Жельвис В. И. Грубость как регулятор коммуникативного поведения // Бытие в языке : сб. науч. трудов к 80-летию В. И. Жельвиса. Ярославль : Изд-во ЯГПУ, 2011. C. 258-289. 
17. Романов А. А. Системный анализ регулятивных средств диалогического общения. М. : Ин-т языкознания АН CCCP, 1988.

18. Апресян В. Ю. Имплицитная агрессия в языке // Компьютерная лингвистика и интеллектуальные технологии : труды Междунар. конф. «Диалог-2003». М., 2003. C. $32-35$.

19. Garfinkel H. The Origins of the Term «Ethnomethodology» // Ethnomethodology / ed. by R. Turner. Baltimore : Pinguin, 1974. Pp. 15-18.

20. Леонтьев В. В. Понятия невежливости и грубости в современной лингвистике // Экология языка и коммуникативная практика. 2013. № 1. С. 131-141.

21. Маслова О. В. Особенности выражения речевой агрессии в коммуникативном поведении русских и англичан // Вестник РУДН. Серия: вопросы образования : Языки и специальность. М., 2013. № 3. С. 22-26.

\section{REFERENCES}

1. Ozhegov S. I., Shvedova N. Ju. Tolkovyj slovar' russkogo jazyka. Izd. 4-e, dop. Moscow, 1997.

2. Bol'shoj psihologicheskij slovar' / pod red. B. G. Meshherjakova i V. P. Zinchenko. Available at: https:// psychological.slovaronline.com/41-AGRESSIYA

3. Bol'shoj tolkovyj sociologicheskij slovar'. Available at: https://gufo.me/dict/social_dict

4. Oxford Advanced Learner's Dictionary. Oxford, 2000.

5. Dictionary.com. Available at: http://dictionary. reference.com/browse/aggression

6. Oxford English Dictionary. Available at: https:// www.oxfordlearnersdictionaries.com/definition/english/ aggression? $\mathrm{q}=$ aggression

7. Jakimova N. S. Verbal'naja agressija kak aktual'nyj fenomen sovremennogo obshhestva. In: Vestnik Kemerov. gos. un-ta. 2011. No. 1 (45). Pp. 184-188.

8. Sokolova O. I. V portfel' specialista-mezhdunarodnika: osoznannaja i neosoznannaja rechevaja agressija. Available at: http://www.my-luni.ru/journal/clauses/75/

Южный федеральный университет, Институт филологии и межкультурной коммуникации

Денисова А. В., доиент

E-mail: avdenisova@sfedu.ru

Поступила в редакциию 5 сентября 2020 г.

Принята к публикаиии 29 декабря 2020 г.

\section{Для цитирования:}

Денисова А. В. Лексико-семантические способы выражения речевой агрессии в английском и русском языках // Вестник Воронежского государственного университета. Серия: Лингвистика и межкультурная коммуникация. 2021. № 1. C. 48-56. DOI: https://doi. org/10.17308/lic.2021.1/3237
9. Sternin I. A. Kommunikativnoe povedenie kak predmet opisanija. Available at: http://homepages.tversu.ru/ susov/Sternin.htm

10. Shherbinina Ju. V. Rechevaja agressija. Territorija vrazhdy. Moscow, 2012. 400 p.

11. Shherbinina Ju. V. Russkij jazyk. Rechevaja agressija i puti ee preodolenija : ucheb. posobie. Moscow, 2018. 224 p. Available at: https://www.litmir.me/ $\mathrm{br} / \mathrm{pb}=211416 \& \mathrm{p}=1$

12. Bjeron R., Richardson D. Agressija. St. Petersburg, 1998, $336 \mathrm{p}$.

13. Collins English Dictionary. Available at: https:// www.collinsdictionary.com/dictionary/english/moon

14. Izard K. E. Jemocii cheloveka. Moscow, 1980, $552 \mathrm{p}$.

15. Buss A. H. \& Perry M. The aggression questionnaire. In: Journal of Personality and Social psychology. 1992. No. 63. Pp. 452-459.

16. Zhel'vis V. I. Grubost' kak reguljator kommunikativnogo povedenija. In: Bytie $v$ jazyke: sb. nauch. tr. $k$ 80-letiju V. I. Zhel'visa. Yaroslavl, 2011. Pp. 258-289.

17. Romanov A. A. Sistemnyj analiz reguljativnyh sredstv dialogicheskogo obshhenija. Moscow, 1988.

18. Apresjan V. Ju. Implicitnaja agressija v jazyke. In: Komp'juternaja lingvistika i intellektual'nye tehnologii. Trudy Mezhdunarodnoj konferencii Dialog. Moscow, 2003. Pp. 32-35.

19. Garfinkel H. The Origins of the Term «Ethnomethodology». In: Ethnomethodology / ed. By R. Turner. Baltimore, 1974. Pp. 15-18.

20. Leont'ev V. V. Ponjatija nevezhlivosti i grubosti v sovremennoj lingvistike. In: Jekologija jazyka i kommunikativnaja praktika. 2013. No. 1. Pp. 131-141.

21. Maslova O. V. Osobennosti vyrazhenija rechevoj agressii v kommunikativnom povedenii russkih i anglichan. In: Bulletin of Russian Peoples Friendship University. Series Problems of education: lanquages and speciality. M., 2013. No. 3. Pp. 22-26

Rostov-on-Don, Southern Federal University, Institute of Philology and Intercultural Communication

Denisova A. V., Associate Professor

E-mail: avdenisova@sfedu.ru

Received: 5 September 2020

Accepted: 29 December 2020

\section{For citation:}

Denisova $A$. $V$. Lexico-sematic ways of expressing verbal aggression in the English and Russian languages. Proceedings of Voronezh State University. Series: Linguistics and Intercultural Communication. 2021. No. 1. Pp. 4856. DOI: https://doi.org/10.17308/lic.2021.1/3237 